\title{
Life history, ecology and the biogeography of strong genetic breaks among 15 species of Pacific rockfish, Sebastes
}

\author{
Arjun Sivasundar $\cdot$ Stephen R. Palumbi
}

Received: 15 April 2009 / Accepted: 2 March 2010 / Published online: 27 March 2010

(C) Springer-Verlag 2010

\begin{abstract}
Strong genetic change over short spatial scales is surprising among marine species with high dispersal potential. Concordant breaks among several species signals a role for geographic barriers to dispersal. Along the coast of California, such breaks have not been seen across the biogeographic barrier of Point Conception, but other potential geographic boundaries have been surveyed less often. We tested for strong-population structure in 11 species of Sebastes sampled across two regions containing potential dispersal barriers, and conducted a meta-analysis including four additional species. We show two strong breaks north of Monterey Bay, spanning an oceanographic gradient and an upwelling jet. Moderate genetic structure is just as common in the north as it is in the south, across the biogeographic break at Point Conception. Gene flow is generally higher among deep-water species, but these conclusions are confounded by phylogeny. Species in the subgenus Sebastosomus have higher structure than those in the subgenus Pteropodus, despite having larvae with longer pelagic phases. Differences in settlement behavior in the face of ocean currents might help explain these differences. Across similar species across the same coastal environment, we
\end{abstract}

Communicated by M. I. Taylor.

A. Sivasundar · S. R. Palumbi

Department of Biological Sciences, Hopkins Marine Station,

Stanford University, 120 Oceanview Boulevard,

Pacific Grove, CA 93950, USA

A. Sivasundar $(\square)$

Division of Aquatic Ecology,

Institute of Ecology and Evolution, University of Bern,

Baltzerstrasse 6, 3012 Bern, Switzerland

e-mail: arjun.sivasundar@iee.unibe.ch document a wide variety of patterns in gene flow, suggesting that interaction of individual species traits such as settlement behavior with environmental factors such as oceanography can strongly impact population structure.

\section{Introduction}

For many marine species, larval dispersal is a critical part of migration ability, and life history differences between species can dramatically affect gene flow. Investigations of genetic differences among marine populations have been widely used to gauge levels of dispersal, which often scale with larval traits such as pelagic duration (e.g. Berger 1973; Bohonak 1999; Marko 2004). Species for which larval duration is short or absent have often been found to have strong genetic structure among invertebrates (McMillan et al. 1992; Hellberg 1994, 1996) and fishes (e.g. Waples 1987; Doherty et al. 1995; Riginos 2001; Purcell et al. 2006). However, unexpectedly strong structure has also been demonstrated for some species that are presumed to have long distance dispersal potential (e.g. Reeb et al. 2000; Barber et al. 2002; Burford and Bernardi 2008). Uncovering the reasons for strong genetic breaks in such species can potentially reveal a great deal about larval mechanisms that limit dispersal.

Some of the clearest explanations of strong genetic breaks derive from the observation that in some cases, these breaks are concordant with strong biogeographic boundaries. Taxa as diverse as coastal birds, tortoises, fish and invertebrates show strong geographic differentiation along the southeastern coast of the United States (Avise 1992, 1996). Other cases of the confluence of genetic and biogeographic breaks in the oceans have been found in Indonesia, the western Mediterranean, the East Pacific and the Red Sea 
(Palumbi 1996, 1997; Sanjuan et al. 1996; Lessios et al. 2001). In these cases, the confluence of genetic breaks across the same geographic feature suggests that the genetic patterns do not derive from specific traits of these species alone, but also depend on barriers to dispersal created by geographic or oceanographic features (Avise 1996).

Though some well-known biogeographic breaks show genetic concordance, others do not. In particular, the major biogeographic break at Point Conception in California is a major region of genetic change in only a handful of species examined (Burton 1998; Dawson 2001). However, strong genetic change may occur in other sections of the coast for other species, and it is possible that genetic concordance occurs along the west coast of North America, near features other than Point Conception.

This region is home to a number of strong ecological gradients that could have an effect on population structure. Between northern California and Oregon, there is a shift in upwelling conditions that increase Oregon nearshore productivity, larval settlement and the growth of many adults of nearshore species (Roughgarden et al. 1988; Connolly and Roughgarden 1998; Connolly et al. 2001; Menge et al. 2004). The center of this shift is Cape Mendicino, a region of strong upwelling that creates persistent offshore movement of nearshore water masses.

Current information on the genetics of coastal populations along this coast offers conflicting data for different species. Intertidal mussels (Mytilus californianus) have no structure across a range of genetic markers (Addison et al. 2008), and the shallow water sea urchin Strongylocentrotus purpuratus has been shown to have similar mtDNA and allozyme patterns along this coast (Palumbi and Wilson 1990; Edmands et al. 1996; Flowers et al. 2002). Some rockfish show mild genetic differentiation in an isolationby-distance pattern along the coast (Buonaccorsi et al. 2002). By contrast, the blue rockfish Sebastes mystinus shows striking genetic changes near Cape Mendicino despite having a long-term planktonic larval stage (Burford and Bernardi 2008).

Understanding the position and the strength of genetic breaks along the west coast of North America is an important component of understanding the dynamics of this complex ecosystem. Whether dispersal across upwelling jets is common, whether the species inhabiting the nearcontinuous coastal kelp forest recruit from a common gene pool, and whether other coastal features besides prominent biogeographic breaks can serve as concordant genetic breaks are all questions that might be answered by searching for strong genetic differentiation along this coast. This information also has implications for nearshore fisheries management and of marine protected area networks designed to function within ocean areas between upwelling jets.
Here, we compare population genetic patterns of 11 species of the rockfish genus Sebastes sampled in three areas along the west coast of the United States in order to probe for strong genetic structure, and to test the relationship of genetic patterns to adult and larval traits. Adults of Sebastes spp. are generally non-migratory and often have limited home ranges. However, these species have pelagic larval durations that last from 1 to 4 months. Previous studies have suggested that species inhabiting shallow water as adults may in general show more consistent genetic structure than do species inhabiting deep, offshore habitats (Rocha-Olivares et al. 1999; Buonaccorsi et al. 2002, 2004).

We designed a sampling scheme encompassing species with different adult habitat requirements by including nearshore demersal species (copper rockfish, Sebastes caurinus; gopher rockfish, S. carnatus; brown rockfish, S.auriculatus; black rockfish, S. melanops; olive rockfish, S. serranoides and blue rockfish, $S$. mystinus) as well as species that occur in deeper waters (bocaccio, S. paucispinis; widow rockfish, S. entomelas; yellowtail rockfish, S. flavidus; starry rockfish, S. constellatus; and vermilion rockfish, S. miniatus). These species also fall into subgenera that differ in potential dispersal abilities. The subgenus Sebastosomus (Eigenmann and Beeson 1893) was defined on the basis of skull and spine traits, and consists of five species, namely black, olive, yellowtail, widow and blue rockfish, all of which have a relatively long larval period (3-4 months). By contrast, the subgenus Pteropodus (including kelp, gopher, copper, brown, grass and black-and-yellow rockfish) has shorter a pelagic development period (1-2 months; Carr and Syms 2006).

Comparing many species at many loci often precludes fine-grained geographic detail. Here, we adopt a coarse sampling strategy that focuses on only three areas: the Oregon coast (hereafter OR), Monterey Bay (MB), and the southern California shore near Santa Barbara (SB; Fig. 1). These three sites span the biogeographic boundary at Point Conception between Monterey and Santa Barbara, and span the ecological gradient between Monterey and Oregon. They are also nested within different oceanic regimes (Parrish et al. 1981), being separated by upwelling jets at Cape Mendocino and Point Conception. We use this design to determine what species show genetic distinctions across these boundaries. Clearly, such a sampling strategy cannot uncover genetic differentiation at small spatial scales. Its strength, instead, lies in a highly comparative data set of differences at the same genetic loci for a range of different species in different areas. Starting from this base, we also collected data from the literature on structure of other Sebastes species from the west coast of North America and conducted a metadata analysis to evaluate the impact of adult habitat, phylogeny and larval duration on genetic differentiation. 


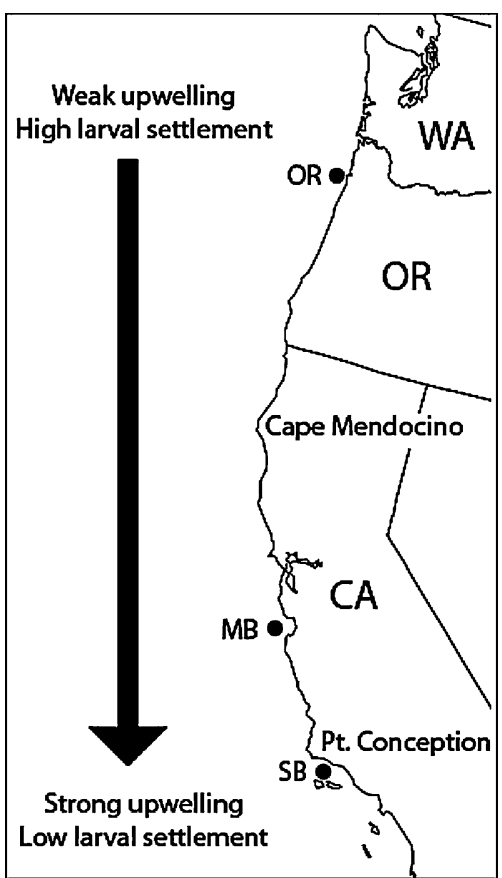

Fig. 1 Map of California and Oregon showing the location of sampling of new populations analyzed here, along with the locations of the biogeographic barrier at Pt. Conception and the ecological gradient along the coast

\section{Methods}

Samples and data collection

Fin clips from individuals of all species were collected on board sport-fishing vessels in Santa Barbara, CA (hereafter $\mathrm{SB})$, Monterey, CA (MB) and Garibaldi, OR (OR). Clips were sorted by species and immediately stored in $70 \%$ ethanol. Genomic DNA was extracted from fin clips by boiling a small piece of tissue in 10\% Chelex (Bio-Rad Laboratories). A portion of the mitochondrial control region was amplified by PCR using the forward primer L15876 (5'-AAGCACTTGAATGAGCTTG) and the reverse primer H16498 (5'-CCTGAAGTAGGAACCAGATG) (Meyer et al. 1990). In some cases where amplification failed, the forward primer K (5'-AGCTCAGCGCCAGAGCGCCGG TCTTGTAAA) was used instead (Lee et al. 1995). PCR products were sequenced in one direction using the forward PCR primer. Sequences were assembled and aligned using Sequencher 4.6 (Gene Codes Corporation).

Microsatellite loci developed in various species of Sebastes were also amplified from these samples. The loci Sal1, Sal2 and Sal3 from S. alutus (Miller et al. 2000), Sma2, Sma4, Sma5 and Sma10 from S. maliger (Wimberger 1999) and Sra5-9, Sra7-2, Sra7-7 and Sra7-25 from
S. rastrelliger (Buonaccorsi et al. 2004; Westerman et al. 2005) were screened using the primers and protocols described in those studies. Amplifications were performed using 5' fluorescently labeled primers (Applied Biosystems) and genotyped on an ABI-3730 DNA Analyzer (Applied Biosystems). Allele calls were made using GeneMapper 4.0 (Applied Biosystems) and inspected visually for accuracy.

\section{Statistical analyses}

Genetic differentiation among populations of each species was estimated as $\Phi_{\mathrm{ST}}$ from control region sequences using Arlequin 2.001 (Schneider et al. 2000) using the Kimura 2parameter model of DNA substitution. Relationships among individuals and populations were also estimated by constructing a neighbor-joining tree for each species using PAUP 4.0b (Swofford 1998).

The degree of population subdivision within species was estimated using the mitochondrial control region sequences based on standard $\Phi_{\mathrm{ST}}$ analysis as well as multilocus microsatellite genotypes. For the microsatellites, in addition to standard estimates of population differentiation based on $F_{\mathrm{ST}}$ and $R_{\mathrm{ST}}$, we used a non-parametric test for population structure based on assignment probabilities that asks whether individuals are assigned back to their native population more often than strictly due to chance. A visual examination of the plots for each population comparison provides an estimate of how frequently individuals were assigned back to the population they were sampled from. The $P$ values in each panel list the nonparametric probability that the assignment shown occurred by chance. The results of tests of population structure are presented in detail in the "Appendix" and are summarized in Table 3.

Microsatellite loci were examined for deviations from Hardy-Weinberg equilibrium (HWE) using the web version of GENEPOP v3.3 (http://genepop.curtin.edu.au) (Raymond and Rousset 1995). Expected and observed heterozygosities were calculated using Arlequin 2.001 (Schneider et al. 2000). Genetic differentiation among populations of each species was also estimated using Arlequin 2.001. Two measures of genetic differentiation were used for the microsatellite analyses: $F_{\mathrm{ST}}$, which does not explicitly account for a mutational mechanism, and $R_{\mathrm{ST}}$, which does (Slatkin 1995). Assignment tests were also performed to assess how distinct individuals from one population of a species were from individuals from another population (Paetkau et al. 1995). Assignment probabilities were generated using the software program Doh (http://www2.biology.ualberta.ca/jbrzusto/Doh.php). Significance of the assignments was assessed using a $2 \times 2$ contingency test. 
Table 1 Sample sizes $(N)$, estimates of the population parameter $\theta_{S}$ and haplotype diversity $H$ for the mitochondrial control region in 11 species of Sebastes

\begin{tabular}{|c|c|c|c|c|c|c|c|c|c|c|c|c|c|c|c|}
\hline & \multicolumn{5}{|c|}{ MB } & \multicolumn{5}{|l|}{ OR } & \multicolumn{5}{|l|}{ SB } \\
\hline & $N$ & $\theta_{S}$ & $H$ & Hap & Pvt & $N$ & $\theta_{S}$ & $H$ & Hap & Pvt & $N$ & $\theta_{S}$ & $H$ & Hap & Pvt \\
\hline \multicolumn{16}{|c|}{ Shallow-water species } \\
\hline Blue & 22 & 9.876 & 0.974 & 17 & 15 & 23 & 13.005 & 0.992 & 21 & 20 & 28 & 13.877 & 0.979 & 23 & 20 \\
\hline Black & 24 & 4.552 & 0.862 & 14 & 12 & 19 & 3.433 & 0.877 & 12 & 10 & & & & & \\
\hline Olive & 30 & 6.815 & 0.908 & 19 & 10 & & & & & & 33 & 7.885 & 0.964 & 12 & 3 \\
\hline Copper & 18 & 6.396 & 0.895 & 13 & 12 & 18 & 7.850 & 0.987 & 16 & 15 & 9 & 12.142 & 0.972 & 8 & 8 \\
\hline Gopher & 18 & 12.211 & 0.994 & 18 & 17 & & & & & & 26 & 12.841 & 0.982 & 23 & 22 \\
\hline Brown & 23 & 5.961 & 0.957 & 16 & 9 & & & & & & 29 & 4.329 & 0.946 & 18 & 11 \\
\hline \multicolumn{16}{|c|}{ Deep-water species } \\
\hline Yellowtail & 27 & 4.151 & 0.926 & 17 & 11 & 18 & 4.361 & 0.922 & 13 & 11 & 22 & 4.664 & 0.974 & 17 & 11 \\
\hline Widow & 15 & 7.996 & 0.857 & 11 & 9 & & & & & & 36 & 13.746 & 0.929 & 22 & 20 \\
\hline Bocaccio & 10 & 3.535 & 0.867 & 7 & 5 & & & & & & 14 & 4.088 & 0.879 & 9 & 7 \\
\hline Starry & 27 & 13.232 & 0.983 & 10 & 4 & & & & & & 28 & 11.307 & 0.989 & 20 & 14 \\
\hline Vermilion & 16 & 3.315 & 0.817 & 22 & 17 & & & & & & 47 & 14.943 & 0.899 & 25 & 20 \\
\hline
\end{tabular}

The number of haplotypes (Hap) and the number of those not found in any other population (private haplotypes; Pvt) are also shown for each population

\section{Results}

We collected mtDNA sequence and microsatellite genotype data from 578 individuals of 11 species from three locations along the west coast of North America to discern major patterns of population structure across species and compare these with biogeographic and ecological differences. Because all species do not range across the sampling area, and because some species are rare at their range edges, only three of 11 species were compared across all three sites. One species, black rockfish, is not found in Santa Barbara and was only compared to the north of Monterey. Seven species were rare or unavailable from Oregon and were compared to the south of Monterey. Data were collected for the mitochondrial control region and for 5-7 microsatellites per individual. Samples sizes averaged above 20 individuals per location except for bocaccio and copper rockfish ( $N=12$ and 15 per location, respectively). For these species, we supplement our data in the metadata analysis with published data (Buonaccorsi et al. 2002; Matala et al. 2004). Details are reported in the "Appendix".

\section{Genetic diversity}

Haplotype diversity at the mitochondrial control region was high, with average estimates ranging from 0.858 in vermilion rockfish to 0.988 in gopher rockfish. The number of segregating sites within approximately $400 \mathrm{bp}$ of control region sequences within species $\left(\theta_{\mathrm{S}}\right)$ ranged from 4 to 15 . See Table 1 for sample sizes and estimates of diversity by species for the control region data. Neighbor-joining (NJ) trees were constructed for each species using control region sequence from a congener (speckled rockfish, $S$. ovalis) to root the trees. Only in two of the species was there marked clustering of haplotypes by geographic origin. For blue rockfish, the majority of the OR samples of blue rockfish form a clade, which also includes one individual from each of the other populations (Fig. 2a). In yellowtail rockfish, again the tree revealed strong clustering by geographic location (Fig. 2b). Almost all the OR samples form a single clade, which does not include any samples from either of the other populations. One other case of two divergent lineages was evident from the $\mathrm{NJ}$ trees: in vermilion rockfish some of our SB samples fall into a deeply divergent mtDNA clade (Fig. 2c). This is discussed further below. Phylogenetic trees for the remaining species showed no strong evidence of clustering by sampling location.

The microsatellite loci showed an average of 9.5 alleles over all loci over all species. Among loci, the number of alleles ranged from 6.4 to 14.0 , while among species there were between 4.4 (in widow rockfish) and 13.7 (in vermilion rockfish) alleles per locus. Allelic variation by species and by locus is shown in Table 2. Across species, there was no statistically significant relationship between allelic diversity for microsatellite loci and $\theta_{\mathrm{S}}$ values for the control region.

Most microsatellite loci were in concordance with Hardy-Weinberg equilibrium (HWE) in all species except vermilion. In cases where HWE was violated, further analyses 
(a)

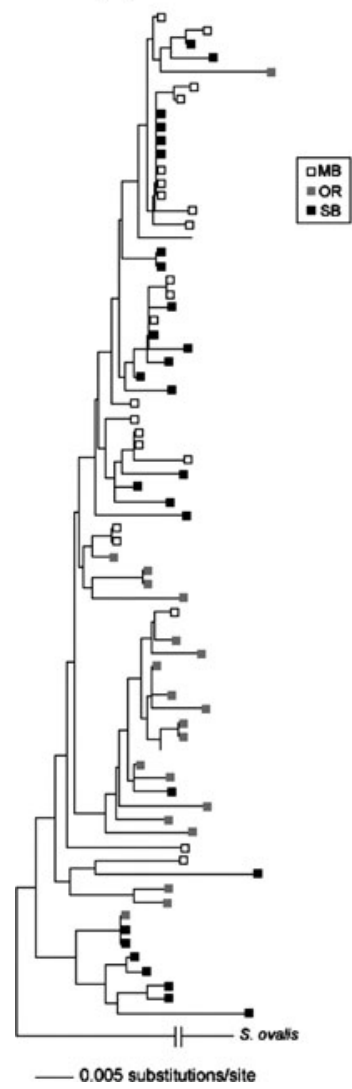

(b)

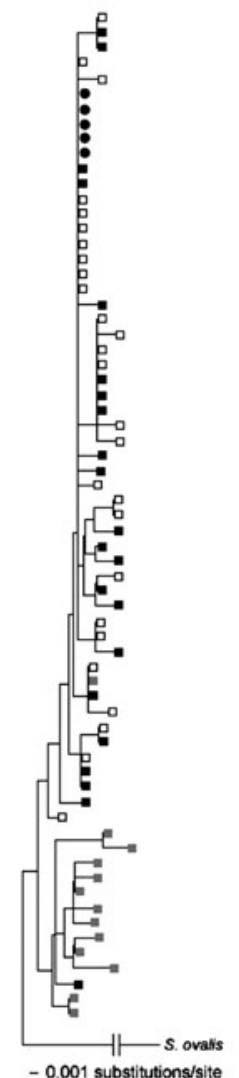

(c)

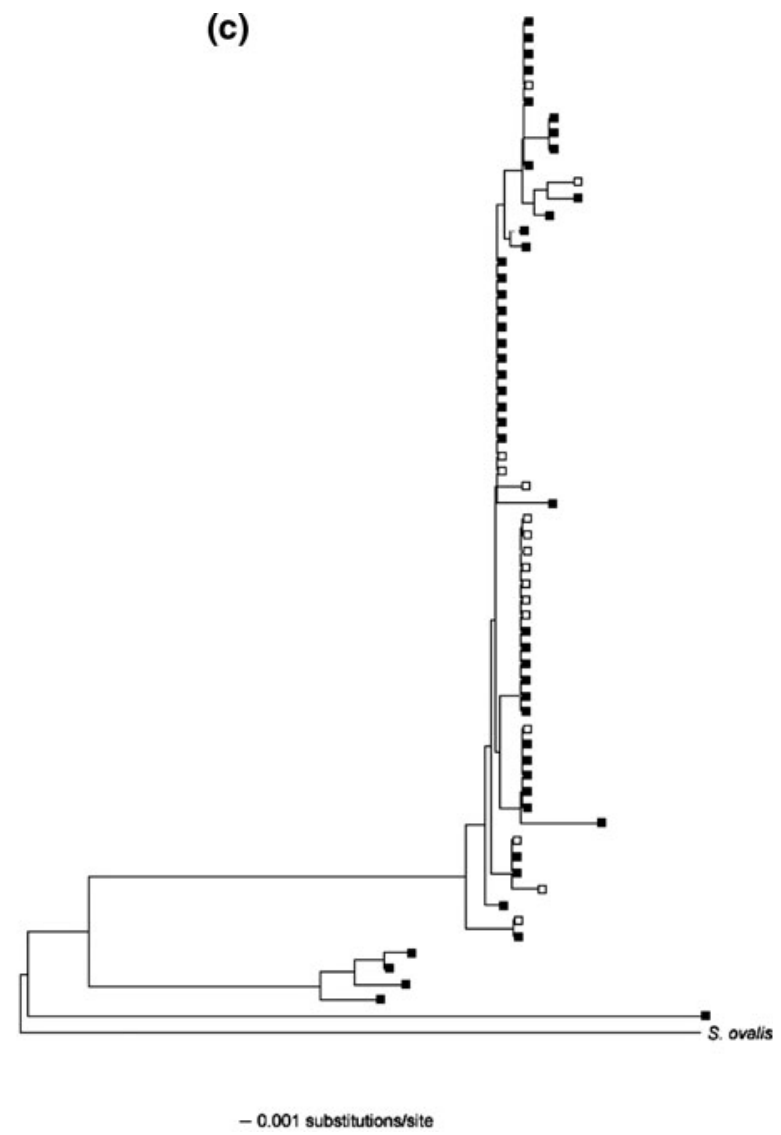

Fig. 2 Neighbor-joining trees of control region sequences for $\mathbf{a}$ blue, $\mathbf{b}$ yellowtail and $\mathbf{c}$ vermilion rockfish

Table 2 The number of alleles at microsatellite loci for 11 species of Sebastes

\begin{tabular}{lllllllllr}
\hline & Sal2 & Sal3 & Sma2 & Sma4 & Sma5 & Sma10 & Sra7-2 & Sra7-7 & Average \\
\hline Shallow-water species & & & & & & & & \\
Blue & 14 & 7 & & & & 9 & 14 & 12 & 11.2 \\
Black & 7 & 11 & 9 & & 12 & & 27 & 13 & 13.2 \\
Olive & 4 & 8 & 12 & & 8 & 5 & 15 & 7 & 8.4 \\
Copper & 9 & 6 & 3 & & 4 & 15 & & & 7.4 \\
Gopher & 11 & 13 & 7 & & 5 & 20 & & 14 & 11.7 \\
Brown & 4 & 7 & 2 & & 6 & & 4 & & 4.6 \\
Deep-water species & & & & & & & & 13 \\
Yellowtail & 12 & 8 & & 14 & & 8 & 17 & 13 & 12.0 \\
Widow & 2 & 5 & 2 & & 3 & 11 & 3 & 5 & 4.4 \\
Bocaccio & 10 & 16 & 7 & & 7 & 10 & 9 & 13 & 10.3 \\
Starry & 3 & 8 & 6 & & 6 & & 12 & & 7.0 \\
Vermilion & 1 & 10 & 10 & & 11 & 14 & 18 & 19 & 13.7 \\
Average & 7.6 & 9.0 & 6.4 & 14.0 & 6.9 & 11.5 & 13.2 & 12.0 & 9.5 \\
\hline
\end{tabular}

for those species were conducted both including and excluding the loci that were not in HWE. No linkage disequilibrium was detected between any pair of loci in any of the species.
Strong genetic breaks

Genetic breaks occur in the blue rockfish and the yellowtail rockfish, where strong genetic differentiation $\left(F_{\mathrm{ST}}\right.$ or 
Table 3 Summary of population genetic differentiation in 11 species of rockfishes inferred from mitochondrial DNA sequences ( $\left.\Phi_{\mathrm{ST}}\right)$, microsatellites $\left(F_{\mathrm{ST}}\right.$ and $\left.R_{\mathrm{ST}}\right)$ and assignment tests

\begin{tabular}{|c|c|c|c|c|c|}
\hline & mtDNA & Microsatellites & Assignment test & North & South \\
\hline \multicolumn{6}{|l|}{ Shallow-water species } \\
\hline Blue (Sebastosomus) & $0.19 / 0.25 * * *$ & $0.11 * * * /$ & $* * *$ & $\mathrm{Y}$ & $\mathrm{N}$ \\
\hline Black (Sebastosomus) & $0.05 * /$ & - & - & $\mathrm{Y}$ & $\mathrm{n} / \mathrm{a}$ \\
\hline Olive (Sebastosomus) & - & $/ 0.01 *$ & $* *$ & $\mathrm{n} / \mathrm{a}$ & $\mathrm{Y}$ \\
\hline Copper (Pteropodus) & $0.021 / 0.121 * *$ & - & - & $\mathrm{N}$ & $\mathrm{Y}$ \\
\hline Gopher (Pteropodus) & $/ 0.06^{*}$ & - & - & $\mathrm{n} / \mathrm{a}$ & $\mathrm{Y}$ \\
\hline Brown (Pteropodus) & - & $/ 0.02 *$ & $* *$ & $\mathrm{n} / \mathrm{a}$ & $\mathrm{Y}$ \\
\hline \multicolumn{6}{|l|}{ Deep-water species } \\
\hline Yellowtail (Sebastosomus) & $0.25 / 0.01 * * *$ & $0.094 / * * *$ & $* * *$ & $\mathrm{Y}$ & $\mathrm{Y}$ \\
\hline Widow (Sebastosomus) & - & - & - & $\mathrm{n} / \mathrm{a}$ & $\mathrm{N}$ \\
\hline Bocaccio & - & - & $*$ & $\mathrm{n} / \mathrm{a}$ & $\mathrm{N}$ \\
\hline Starry & - & - & - & $\mathrm{n} / \mathrm{a}$ & $\mathrm{N}$ \\
\hline Vermilion type 2 & - & - & - & $\mathrm{n} / \mathrm{a}$ & $\mathrm{N}$ \\
\hline
\end{tabular}

Values are $F_{\mathrm{ST}}$ or $\Phi_{\mathrm{ST}}$ for northern/southern comparisons, followed by symbols for statistical tests: “***” strong and significant differentiation, “**” moderate differentiation, “*” weak but statistically significant differentiation, "-" no significant differentiation. Only significant values are shown. The geographic location of genetic discontinuities, relative to Monterey Bay, is also shown (north, south: $\mathrm{Y}=$ genetic break, $\mathrm{N}=$ no break, $\mathrm{n} / \mathrm{a}=$ comparison not available). Detailed results are presented in "Appendix"

$\left.\Phi_{\mathrm{ST}}>0.1, P \ll 0.01\right)$ occurred between Oregon and Monterey. These patterns are clear for both mtDNA and microsatellites in all analyses (Table 3; Fig. 3). Northern mtDNA differences range from 0.19 to 0.25 for these species while microsatellite variation is 0.09-0.11. Between Monterey and Santa Barbara, only the blue rockfish shows strong differences, driven by an mtDNA clade common only in Santa Barbara (Fig. 2). No other strong breaks were recorded among any of the 11 species between Monterey and Santa Barbara.

\section{Weak population structure}

All the shallow Sebastosomus species (blue, black and olive) show statistically significant structure in mtDNA, microsatellites or both (Table 3). Among the shallow water Pteropodus, copper and gopher rockfish show moderate to slight mtDNA structure but no nuclear structure, and the brown rockfish shows mild nuclear structure without mtDNA differentiation (Table 3).

Except for yellowtail rockfish, deep-water species generally showed little hint of genetic structure. Most other species had no discernable patterns in these tests. An exception is the mild genetic differentiation $(P=0.011)$ in bocaccio seen in our assignment tests (Fig. 3). Other work on this species has also suggested very weak genetic structure along the California coast south of Point Conception (Matala et al. 2004). The vermillion rockfish showed genetic patterns recently revealed to reflect parapartric cryptic species (Hyde and Vetter 2007). We limit our comparison here to vermillion lineage 2, which shows no genetic differentiation between Monterey and Santa Barbara in our small sample. Detailed results for individual species are available in the "Appendix".

Metadata analysis

In addition to the new data on 11 Sebastes species collected in this study, data from grass, black-and-yellow, kelp and chilipepper rockfish are available from the literature (Wishard et al. 1980; Buonaccorsi et al. 2004; Narum et al. 2004; Gilbert-Horvath et al. 2006). These data are largely based on microsatellite comparisons of populations along the Washington-Oregon-California coast. To include these data, and in order to summarize our new data from the aforementioned sections, we tabulated comparisons of population differences between Oregon/Washington and Monterey and between Monterey and southern California. We gave each comparison a score of 0,1 or 2 depending on whether it showed no differentiation, mild differentiation $(P$ values between 0.01 and 0.05 ) or strong differentiation $(P \ll 0.01)$, respectively. We included three kinds of genetic comparisons: mtDNA, microsatellite $\left(F_{\mathrm{ST}}\right.$ or $\left.R_{\mathrm{ST}}\right)$

Fig. 3 Plots of likelihoods of assignment tests showing the likelihoods of individuals belonging to each of populations compared. $P$ values shown on the plots are the probabilities that the observed assignments were the result of chance. The solid diagonal line indicates equal probability of being assigned to one population or the other. Points outside the dotted lines are assigned to one population with more than ten times the likelihood as the other one 

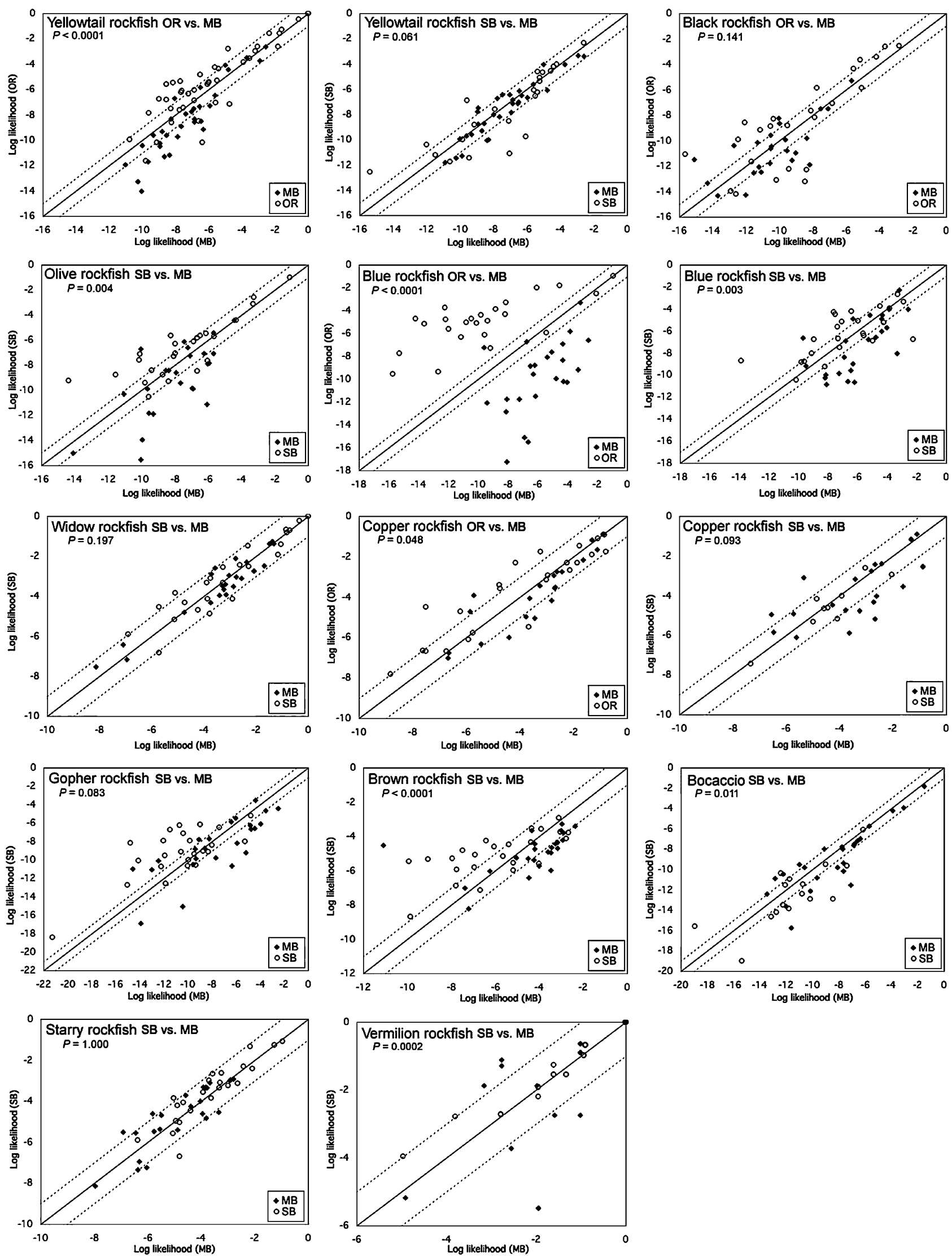

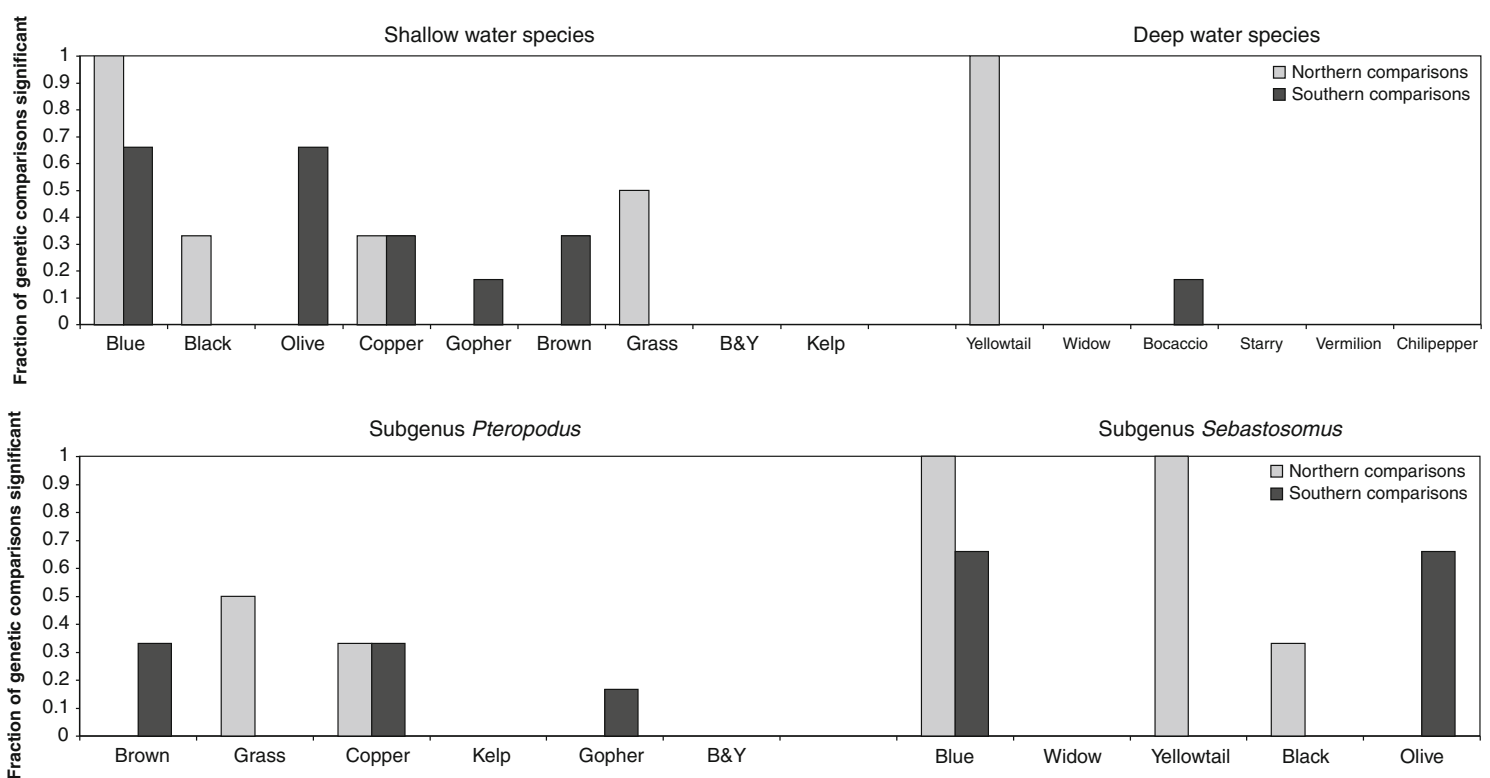

Fig. 4 Prevalence of population substructuring in comparisons to the north and to the south of Monterey Bay among shallow and deep-water species (top panel) and among species of the subgenera Sebastosomus and Pteropodus (bottom panel). Results derive from data collected in this study and from the literature. For references to data sources see Table 4

Table 4 Summary of population genetic differentiation in 15 species of rockfishes, using data from this and other studies, inferred from mitochondrial DNA sequences $\left(\Phi_{\mathrm{ST}}\right)$, microsatellites $\left(F_{\mathrm{ST}}\right.$ and $\left.R_{\mathrm{ST}}\right)$ and assignment tests

\begin{tabular}{|c|c|c|c|c|c|c|c|c|c|c|c|c|c|c|c|}
\hline & \multicolumn{9}{|c|}{ Shallow-water species } & \multicolumn{6}{|c|}{ Deep-water species } \\
\hline & Blu & Blk & $\mathrm{Olv}$ & Cop & Gop & Brn & Grs & $\mathrm{B} \& \mathrm{Y}$ & Kel & Yel & Wid & Boc & Sta & Ver & Chi \\
\hline \multicolumn{16}{|l|}{ mtDNA } \\
\hline OR-MB & 2 & 1 & & 0 & & & & & & 2 & & & & & \\
\hline MB-SB & 2 & & 0 & 1 & 1 & 0 & & & & 0 & 0 & 0 & 0 & 0 & \\
\hline \multicolumn{16}{|l|}{ Microsatellite } \\
\hline OR-MB & 2 & 0 & & 0 & $0^{* 1}$ & $0 * 2$ & $1 *^{3}$ & $0 * 1$ & & 2 & & 0 & & & $0 * 5$ \\
\hline MB-SB & 1 & & 1 & 0 & 0 & 0 & $0 *^{3}$ & $0 * 1$ & $0^{* 4}$ & 0 & 0 & 0 & 0 & & $0 * 5$ \\
\hline \multicolumn{16}{|l|}{ Assignment } \\
\hline OR-MB & 2 & 0 & & 1 & & & & & & 2 & & & & & \\
\hline MB-SB & 1 & & 1 & 0 & 0 & 2 & & & & 0 & 0 & 1 & & & \\
\hline Northern & $6 / 6$ & $1 / 6$ & & $1 / 6$ & $0 / 2$ & $0 / 2$ & $1 / 2$ & $0 / 2$ & & $6 / 6$ & & $0 / 2$ & & & $0 / 2$ \\
\hline Southern & $4 / 6$ & & $2 / 6$ & $1 / 6$ & $1 / 6$ & $2 / 6$ & $0 / 2$ & $0 / 2$ & $0 / 2$ & $0 / 6$ & $0 / 6$ & $1 / 6$ & $0 / 6$ & $0 / 2$ & $0 / 2$ \\
\hline Northern comparisons & 1 & 0.33 & & 0.33 & 0 & 0 & 0.5 & 0 & & 1 & & 0 & & & 0 \\
\hline Southern comparisons & 0.66 & & 0.66 & 0.33 & 0.167 & 0.33 & 0 & 0 & 0 & 0 & 0 & 0.167 & 0 & 0 & 0 \\
\hline
\end{tabular}

Scores of 2, 1 and 0 imply strong differentiation, moderate differentiation and non-significant differentiation, respectively. Data with asterisks derive from other published studies as follows: 1: Narum et al. (2004); 2: Buonaccorsi et al. (2005); 3: Buonaccorsi et al. (2004); 4: Gilbert-Horvath et al. (2006); 5: Wishard et al. (1980)

Blu blue, blk black, olv olive, cop copper, brn brown, grs grass, $B \& Y$ black and yellow, kel kelp, yel yellowtail, wid widow, boc bocaccio, sta starry, ver vermilion, chi chilipepper

and assignment tests. We divided the score for each case by the maximum possible given the data available. For example, species for which both geographic comparisons and all three types of genetic tests are available can have a maximum score of six.
Nine of 15 rockfish species show some level of population structure north or south of Monterey (Fig. 4). Six of 14 comparisons between Monterey and Point Conception, and five of nine comparisons north of Monterey are significant. The strongest differences are in blue rockfish and in yellowtail 
rockfish, both of which show strong differentiation to the north of Monterey. Deep-water species show less structure (two of six species) than shallow-water species (seven of nine species; Fig. 4 upper panel).

However, the data are also consistent with a phylogenetic difference in structure. Species in the subgenus Sebastosomus (blue, widow, yellowtail, black and olive rockfish) show higher structure (5 of 7 comparisons, Fig. 4 lower panel) than species in the subgenus Pteropodus (5 of 11 comparisons). These patterns remain visible even among shallow-water species but the number of species compares is currently small. Though further data are warranted, the three shallow water Sebastosomus for which we have data show as high or higher structure than the six shallow water Pteropodus for which data are available.

\section{Discussion}

Among 15 species of the rockfish genus Sebastes, we find a wide variety of genetic patterns ranging from sharp genetic breaks in all tests for two species to no differentiation in three. The rest shows moderate to slight variation, about equally distributed across Cape Mendicino and Point Conception. These differences are similar in magnitude to those that have been reported among species with large differences in dispersal potential-often among invertebrates or fish with planktonic feeding larvae compared to non-feeding larval types (McMillan et al. 1992; Bernardi 2000, 2005). Yet these Sebastes rockfish species share similar traits, namely internal fertilization with pelagic feeding larvae (Love et al. 2002). This variety of genetic patterns across the same coastline for similar species might be explained by a number of life history and other speciesspecific traits.

Inference based on coarse geographic sampling

The coarse-grained nature of the geographic sampling scheme employed in this study cannot, by design, provide a detailed appraisal of spatial genetic structure within individual species. Instead, it focuses on asking whether genetic structure exists over large distances, and provides a mechanism to collect comparable data sets for many loci across many species. Though this approach provides no data for intervening locations, species lacking genetic differentiation at this broad spatial scale are unlikely to harbor strong hidden structure at finer scales. Cases of strong genetic differentiation in coastal marine species seldom show a patchwork where strongly differentiated populations are interspersed with genetically indistinguishable ones. Possible exceptions may occur when species occur in different habitats such as open coasts and estuaries (Mulvey et al. 2002) or in specific microhabitats (Schmidt and Rand 2001). In European eels, genetic differentiation at some locations has been traced to differences in genetics of settling cohorts, which creates a mild patchwork of genetic structure (Dannewitz et al. 2005). These mild spatially disjunct patterns of genetic differentiation, which also have been described as chaotic patchiness (Planes and Lenfant 2002), may not be detected by our coarsegrained approach though our examination of mtDNA and multiple nuclear loci increases this likelihood.

At the same time, species that do show differentiation at this scale warrant further investigation at finer spatial scales. Detection of strong genetic differentiation from Monterey to Oregon, for example in blue and yellowtail rockfish, leaves open the possibility that the species show abrupt genetic breaks, wide genetic clines or gradual isolation by distance. In each of these cases, reduced larval gene flow is indicated, though the geography of this reduction is likely to be very different for these different patterns. In such cases, finer scale geographic study is warranted. Recently, Burford and Bernardi (2008) traced the fine scale differentiation of blue rockfish to the region around Cape Mendocino. By contrast, study of the fine scale patterns of genetic differentiation in barnacles has shown a 500-km cline in gene frequencies (Sotka et al. 2004). Isolation by distance patterns in rockfish tend to produce relatively low levels of differentiation-often about 0.01 difference in $F_{\text {ST }}$ over 1,000-2,000 km (Buonaccorsi et al. 2004) — and so it is less likely that the large differences we see in yellowtail rockfish are due to this mechanism.

Though coarse-grained sampling has drawbacks, the critical value of such an approach is to generate a highly comparative data set across many species where geography and statistical power are controlled for. In this case, differences between species are more likely to be biological in origin rather than artifacts of sampling. In the past, this approach has provided key insights into the determinants of population genetic structure of fish (e.g. Waples 1987; Doherty et al. 1995; Shulman and Bermingham 1995) even without the spatial scale of sampling that is typically employed in investigations of single species. Because marine communities are made up of so many species with such different potential dispersal patterns (Shanks and Eckert 2005) and because the connectivity of species among locations is a primary part of efforts to understand and manage whole marine ecosystems 
(Palumbi 2003), data on genetic structure of many species from within an ecosystem are an important future goal. Coarse-grained genetic surveys may be an efficient first step in collecting such data.

\section{Geographic correlates of differentiation}

Although the biogeographic break at Point Conception has received the most attention from population geneticists (e.g. Burton 1998; Dawson 2001; Buonaccorsi et al. 2002, 2004), the coast of California is home to a large number of ecological shifts and oceanographic features that may play a role in genetic differentiation. Between Monterey and Oregon, there is a shift in oceanographic conditions that have a strong impact on coastal marine ecosystems (Fig. 1). In Oregon, intermittent upwelling combines high-nutrient pulses with local water retention nearshore, and allows both high larval growth rates and low larval loss offshore. Recruitment is higher by orders of magnitude for coastal invertebrates such as barnacles and mussels (Connolly et al. 2001; Menge et al. 2004). In California, persistent upwelling throughout the summer reduces larval settlement except when occasional upwelling relaxation events allow local larval retention. Major upwelling centers at Cape Mendocino, Point Arena and Santa Cruz in northern California represent major features of the oceanographic landscape and may affect settling marine species.

A number of oceanographic features make Cape Mendocino a particularly likely candidate to reduce connectivity in marine species. This is the area of maximum upwelling within the California Current System (Parrish et al. 1981) because the southern-flowing California Current shifts offshore at this point. Current drifters released near Oregon often move south and then offshore at this point of the coast (Sotka et al. 2004), and as a result, gene flow across this cape may be difficult for species that settle during upwelling conditions. The vicinity of Cape Mendocino is also the area of the local minimum abundances of rockfishes, which are much more common to the north and the south (Gunderson and Sample 1980; Parrish et al. 1981). In addition, the Mendocino Escarpment, a submarine ridge extending out from Cape Mendocino, might limit the amount of nearshore habitat patches available to rockfishes, and serve as a barrier to gene flow (Williams and Ralston 2002; Cope 2004).

Other ecological alterations-some associated with oceanographic differences-occur north of Monterey and cannot be ruled out as correlates of genetic change. The dominant kelp species switches from the perennial Macrocystis pyrifera to the annual species Nereocytis luetkana (Foster and Schiel 1985), altering the under- story algal species, and perhaps changing the nature of nearshore kelp beds where rockfish larvae often recruit. Braby and Somero (2006) described a parallel cline in the dominance of species of bay mussels: Mytilus galloprovincialis is common south of Monterey, and grades into populations dominated by $M$. trossulus to the north. Sotka et al. (2004) described a strong genetic cline in barnacles in this region that is bounded on the north by Cape Mendocino. Overall, the ecological community of California invertebrates shows a marked shift north of Monterey (Blanchette et al. 2008). Our data suggest that tests of geographic concordance of genetic patterns along the west coast of North America expand focus to include Cape Mendicino as a potential barrier to larval dispersal.

\section{Genetic breaks and speciation}

One strong genetic pattern south of Monterey was the distinction in mtDNA between populations of vermillion rockfish. A recent study (Hyde et al. 2008) reported the existence of a cryptic species within $S$. miniatus, and our sampling appears to consist of a mixture of the two types. We sequenced a portion of the cytochrome $b$ gene in order to assign our samples to the types described by Hyde et al. (2008). The divergent SB samples correspond to their "Type 1", while all other samples correspond to their "Type 2". Consistent with their study, Type 1 samples were only found from our site south of Point Conception (SB), while Type 2 was found at both sites. Confining our genetic comparison to the Type 2 'species', we saw no significant difference between Monterey and Santa Barbara.

However, there are unexplained patterns of microsatellite variation in our samples. Most microsatellite loci were out of Hardy-Weinberg equilibrium, showing a strong deficit of heterozygotes even in Monterey where the Type 2 'species' is thought to be allopatric. Analysis with STRUCTURE did not suggest that the nuclear data could be separated into two gene pools, as might be expected if there were two species in Monterey. Dividing the Santa Barbara sympatric population into two on the basis mtDNA lineages did not restore HWE in that location. Both these results suggest that there may be genetically distinct sub-populations of vermillion rockfish left to be discovered, that hybrid genotypes may be strongly selected against, or that mtDNA lineages may not be a perfect indication of species status.

Across Cape Mendicino, a combination of species range summaries, and genetic patterns suggest a similar generation of new species. This geographic feature not only divides species phylogeographically but also marks the shift in numerical dominance among sister species. 
Yellowtail rockfish (S. flavidus) are commonly found from Alaska to southern California (Love et al. 2002), whereas its sister species pair, black and olive rockfishes tends to divide the latitudinal range: olive rockfish (S. serranoides) occur most commonly between Cape Mendocino and Santa Barbara, while black rockfish (S. melanops) are common from Alaska south to northern California, becoming increasingly uncommon further south (Love et al. 2002) (Fig. 5). The part of the coast where these two sister species still overlap coincides with the major biogeographic break in yellowtail rockfish as well as the closely related blue rockfish ( $S$. mystinus; Fig. 5). It is possible that olive and black rockfish represent a more advanced stage in the speciation process than seen within blue rockfish or within yellowtail rockfish, and that in each of these cases, the same geographic factors are at work to limit intraspecific gene flow and spark species differentiation.

Links between species traits and genetic structure

Our data show a wide variety of genetic patterns among similar species across a similar geographic range. This basic result suggests a wide range of realized dispersal distances among species with similar life histories, and allows an examination of the relationship between species traits and genetic structure.

\section{Cladogenesis rates}

Unlike the situation for other marine species, in which rapid speciation is associated with high-population structure (Hansen 1982; Jablonski and Lutz 1983; Duda and Palumbi 1999), we see no such correlation here. Based on the phylogeny and levels of genetic differentiation summarized in (Hyde and Vetter 2007), the rapidly diversifying Sebastosomus clade includes many species with intense-to-moderate-population structure (blue, yellowtail, black, olive), but the Pteropodus clade, diversifying at least as quickly, tends to have low structure (gopher, kelp rockfish, black-and-yellow). Boccacio in its monotypic clade has little structure, but so too does the starry rockfish within its quickly diversifying group. There are numerous reasons why speciation rate and population structure may not correlate: (1) species may be so recent that they extend over small ranges and have little structure yet, (2) recent range expansions after the last glacial maximum may have obscured structure (e.g. Hellberg et al. 2001), (3) species may not form by exclusively allopatric mechanisms, and so the link between dispersal rate and species divergence that drives correlations in other taxa may be broken.

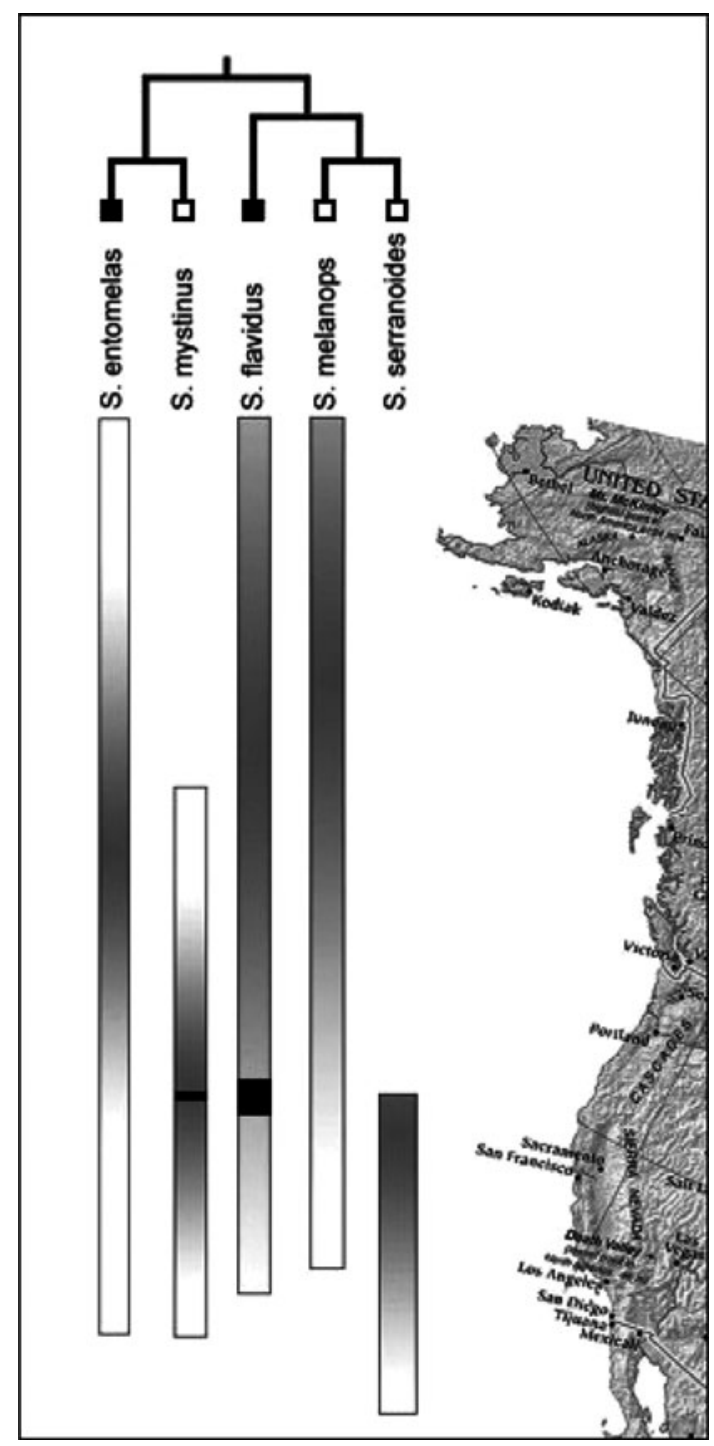

Fig. 5 The biogeography of rockfish in the subgenus Sebastosomus (filled black squares for deep-water species, open squares for shallowwater species) in northern California shows genetic breaks and sister species separation at Cape Mendocino. Vertical bars mark the latitudinal range of five species-shading is an approximate index of density from highest (darkest) to lowest (white). Black areas within ranges represent genetic breaks; their widths are determined by the extent of geographic resolution of exact breakpoints that are available from current studies. The phylogeny is based on mitochondrial cytochrome $b$ (Hyde and Vetter 2007) and control region sequences

\section{Larval duration}

Genetic structure is higher in the subgenus Sebastosomus, with a longer pelagic larval duration than in species within the subgenus Pteropodus which have shorter larval durations (Carr and Syms 2006). This counter-intuitive result might suggest that current information on larval 


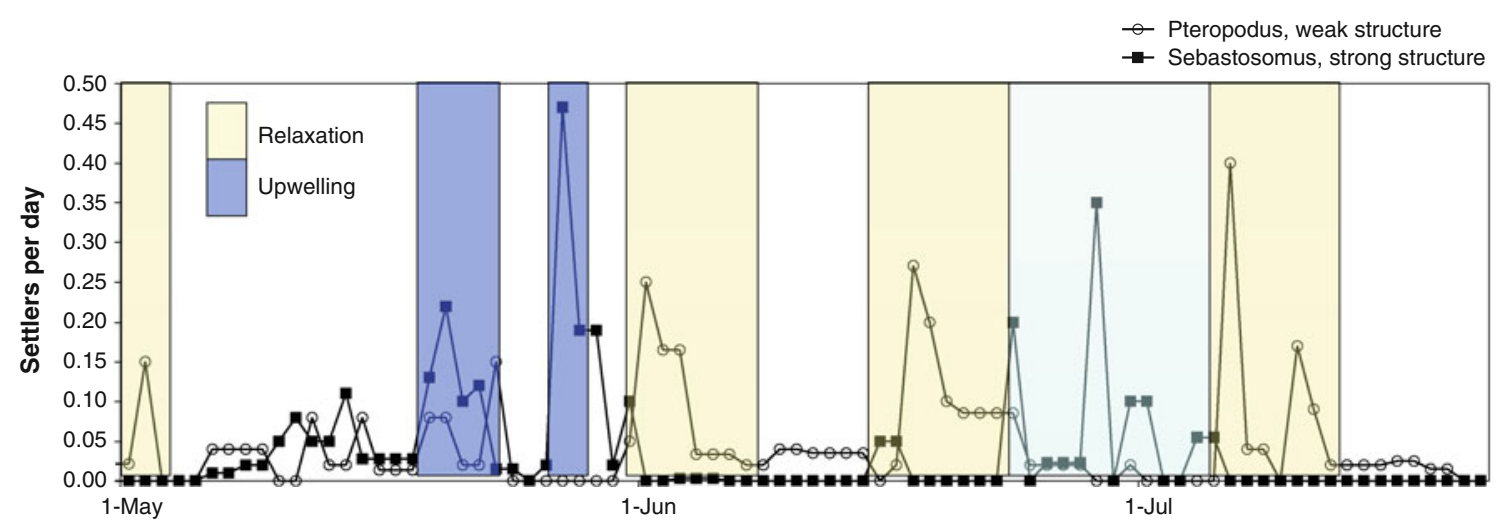

Fig. 6 Settlement patterns of the Sebastosomus clade with strong coastal population structure versus the Pteropodus clade with weak population structure. Species with weak structure appear to settle during warm water periods when upwelling has stopped, perhaps indicat-

durations could reward reexamination. Data on larval duration often compares spawning seasons with settlement seasons (Love et al. 2002; Carr and Syms 2006) rather than being based on direct measurement of larval pelagic phase (but see Miller and Shanks 2004). It is possible that refined measurements of pelagic duration will explain the patterns we present.

\section{Settlement behavior}

For three species of Sebastosomus with moderate to strong structure, yellowtail, olive and black rockfish, larvae are known to recruit during cool water regimes associated with strong upwelling (Lenarz et al. 1995; McManus et al., in preparation; Carr and Syms 2006). By contrast, three closely related species of Pteropodus with zero or low genetic structure-kelp, black-and-yellow, and gophersettle best under the opposite oceanographic conditions, during times of upwelling relaxation when coastal waters warm substantially (Fig. 6). These data are somewhat surprising because they suggest that larvae adapted to settle during conditions of strong upwelling tend not to travel far along the coast, even though upwelling is usually associated with strong larval movement.

One possible explanation is that the intense and consistent upwelling at Cape Mendocino may result in movement of larvae far offshore where they have little chance of return to the coast. Moderate upwelling, by contrast, allows the formation of thin layers of relatively slow-moving water that lie at the interface of surface outgoing and deep incoming water. Phytoplankton and zooplankton tend to accumulate in these areas (McManus et al. 2005), which may be a microhabitat of abundant food. Movement of plankton in these layers has been modeled to be up to ten times slower than just outside these layers (McManus et al. 2005), and so larval behavior mechanisms may play a major role in ing that these larvae are brought into shore by relaxation of offshore current structures, and hence have high dispersal. Species with strong structure appear to settle in the midst of strong upwelling, indicating poorer ability to cross from one upwelling center to another

controlling rockfish settlement patterns. We know of no exploration of species identities of rockfish larval in thin layers, but such a study may allow a test of these ideas.

For species that settle during relaxation conditions, when warmer water persists near shore, two hypotheses have been presented about the origin of larvae. In some cases, these larvae may move from far offshore, being brought back toward the coast when the offshore pressure from upwelled water ceases. In these cases, the larvae have probably come from parents far away. In other cases, the larvae that settle may be local larvae that have not been pushed offshore by upwelling. These 'lucky' local larvae may be the ones to survive and settle, coming from nearby adult populations. The association in our data between settlement during relaxation and low-population structure suggests the lucky local larval hypothesis is not correct for these species and that relaxation events bring in larvae from far away. Buonaccorsi et al. (2004) estimated this dispersal distance as $13 \mathrm{~km}$ or less for grass and copper rockfish based on Rousset's (1997) stepping stone model. This value, however, is highly sensitive to the ratio of total population size to effective population size. Whether this pattern exists in other species that settle during relaxation conditions is not known.

\section{Conclusions and caveats}

Findings from broad-ranging, coarse-grained multispecies studies such as this one come with caveats. First, when comparing several species, as we have done, using the same battery of molecular markers, there is a distinct possibility of ascertainment bias-population structure or the lack thereof could arise as an artifact of using markers developed in one species to study another species. Second, variation between markers can be important. The extent of population structure inferred from a molecular marker can 
be influenced by heterozygosity at that marker \{Hedrick, $2005 \# 600\}$. Third, in some cases sample sizes can be limited, mainly by practical considerations. Despite these caveats, some patterns stand out, and given the geographic coarseness and the phylogenetic breadth of our sampling, we believe these represent real trends.

In conclusion, very different population structures among very similar fish species provide a strong suggestion that simple models of movement of ocean populations based on planktonic period may not be valid. Instead the link between fish biology and movement patterns comes from the combination of fish settlement monitoring in Monterey Bay and the tracking of ocean upwelling. Data from these sources show an unexpected difference between genetically divergent and genetically homogeneous fish species. The genetic results show that not all rockfish species disperse the same way across the same seascape. The oceanographic and settlement results point to strong hypotheses about why these species are so different, and suggest ways of extending the insight from genetics to others species for which genetic data are unavailable. Without the combination of genetics, ecology and oceanography, our efforts to measure dispersal would result in a complex list of very different results. Combining these approaches delivers us a potential mechanistic explanation of the genetic results, and allows us to make predictions that can lead to greater understanding of the role of marine-protected areas of different size or spacing.

Acknowledgments We wish to thank the crews of Stardust Sportfishing (Santa Barbara, CA), Chris' Fishing Trips (Monterey, CA) and Garibaldi Charters (Garibaldi, OR) for assistance in sample collection. We also thank D. Pearse, R. Vetter, M. O. Burford and M. Johansson for providing additional samples. Members of the Palumbi lab provided useful feedback and discussion. We thank M. McManus, M. Carr and P. Raimondi for sharing unpublished data. This study was funded by a grant to SRP from the Andrew W. Mellon Foundation and by the Partnership for Interdisciplinary Studies of Coastal Oceans (PISCO) under grants from the David and Lucille Packard Foundation, and the Gordon and Betty Moore Foundation.

\section{Appendix: Results for individual species}

(1) Population structure in shallow-water species

\section{Blue rockfish S. mystinus}

The large estimates for $\Phi_{\mathrm{ST}}$ between OR and MB populations of blue rockfish $(0.2468 ; P<0.05)$ and between $\mathrm{OR}$ and SB populations $(0.1862 ; P<0.05)$, but not between MB and SB (0.0235; not significant) reflect the clustering evident in the phylogenetic tree. In concordance with the results from control region data, microsatellite data revealed strong genetic differentiation between OR and the other populations of blue rockfish at every individual locus. Assignment tests further corroborated these patterns. Differentiation between OR and MB was extremely strong and highly significant $(P<0.0001)$, and present but less marked between SB and MB $(P<0.003)$.

\section{Black rockfish S. melanops}

For black rockfish, there was a small but significant genetic differentiation between MB and OR $\left(\Phi_{\mathrm{ST}}=0.045\right.$; $P<0.05)$. A single microsatellite locus, Sra7-7, showed significant differentiation between $\mathrm{MB}$ and $\mathrm{OR}$ populations of black rockfish $\left(F_{\mathrm{ST}}=0.029 ; P<0.05\right)$. None of the other loci revealed significant differentiation between the populations, and nor did joint analysis of all loci. Assignment tests corroborated these patterns, with genotype assignment not significantly different from random $(P=0.141)$.

\section{Olive rockfish $S$. serranoides}

For olive rockfish samples from MB and SB, there was little evidence of mtDNA differentiation $\left(\Phi_{\mathrm{ST}}=0.010\right.$; not significant). As with black rockfish, the microsatellite locus, $\mathrm{Sra7}-7$, also showed a statistically significant estimate of genetic differentiation between MB and SB populations. When all loci were jointly analyzed for this species, however, there was weak, but statistically significant differentiation $\left(F_{\mathrm{ST}}=0.010 ; \quad P<0.05\right)$ between populations. Assignment of genotypes to populations in this species was significantly non-random $(P=0.004)$.

\section{Copper rockfish S. caurinus}

The OR and MB populations were both genetically differentiated from the SB populations for mtDNA $\left(\Phi_{\mathrm{ST}}=0.072\right.$ and 0.121 , respectively, $P<0.05$ ), but the MB and OR populations could not be distinguished from each other $\left(\Phi_{\mathrm{ST}}=0.021\right)$. Microsatellite data from copper rockfish from three locations did not reveal the genetic differentiation: one locus was significantly different between OR and SB (Sma10; $\left.F_{\mathrm{ST}}=0.065 ; P<0.05\right)$, but joint analyses did not support this, or any other pairwise differentiation. The assignment tests, however, showed a slight differentiation between OR and MB populations, but not between MB and SB. Though our sample sizes are low for this species, similarly low genetic differentiation was reported by Buonaccorsi et al. (2002), who found only slight differentiation among populations from northern to southern California $\left(F_{\mathrm{ST}}=0.009, P<0.003\right)$. 


\section{Gopher rockfish S. carnatus}

There was evidence for mild genetic differentiation in Gopher rockfish mtDNA $\left(\Phi_{\mathrm{ST}}=0.064 ; P<0.05\right)$. However, joint analysis of all microsatellite loci did not reveal any significant differentiation between these populations nor did genotype assignments differ significantly from random expectations $(P=0.083)$.

\section{Brown rockfish S. auriculatus}

In the third species in this subgroup, there was no significant mtDNA differentiation. Populations of brown rockfish from $\mathrm{MB}$ and $\mathrm{SB}$ were significantly differentiated at the microsatellite locus Sma5 $\left(F_{\mathrm{ST}}=0.092 ; P<0.05\right)$, but not at any of the other loci. When the five loci were combined, however, there was a significant genetic difference between populations $\left(F_{\mathrm{ST}}=0.022 ; P<0.05\right)$. There was also a highly significant difference between populations as assessed by the assignment test $(P<0.0001)$.

\section{(2) Population structure in deep-water species}

Only the yellowtail rockfish showed structure in our survey of five deep-water species, and this structure was very high. However, vermillion rockfish showed a striking pattern of deviation from Hardy-Weinberg equilibrium, and the presence of strikingly different mtDNA clade in Santa Barbara that suggests multiple gene pools in these collections.

\section{Yellowtail rockfish S. flavidus}

The differentiation of mtDNA of yellowtail rockfish from OR and the other populations is borne out by the large estimates for $\Phi_{\mathrm{ST}}$ between OR and MB (0.2542; $P<0.05)$ and between OR and SB $(0.1909 ; P<0.05)$, but not between MB and SB ( -0.0141 , not significant). As with control region data, microsatellite data from yellowtail rockfish again revealed strong evidence of genetic differentiation between $\mathrm{MB}$ and OR samples. There was significant differentiation between these two populations at three of the loci considered individually (Sal2, Sra7-2 and Sma4), and when all loci were considered jointly, excluding one locus that was not in HWE, there was high and significant differentiation whether measured as $R_{\mathrm{ST}}(0.028 ; P<0.05)$ or $F_{\mathrm{ST}}(0.094$; $P<0.05)$. The same three loci also showed some differentiation between SB and OR, but joint analysis of all loci did not yield any significant differentiation between these populations. Between MB and SB, a single locus (Sal2) had a significant $R_{\mathrm{ST}}$ value. Results from the assignment tests revealed the same patterns. Differentiation between OR and MB was marked and highly significant $(P<0.0001)$, while MB and SB were not significantly differentiated $(P=0.061)$.

\section{Widow rockfish S. entomelas}

The widow rockfish showed no patterns of genetic differentiation. There was no evidence for mtDNA differentiation between the populations $\left(\Phi_{\mathrm{ST}}=-0.024\right)$. Microsatellite loci also failed to reveal any differentiation among populations either. A single locus, Sma10, differed slightly between populations $\left(F_{\mathrm{ST}}=0.087 ; P<0.05\right)$. Joint analysis of all loci failed to reveal differentiation between the populations, whether examined by $F_{\mathrm{ST}}$ and $R_{\mathrm{ST}}$ or by assignment tests $(P=0.197)$.

\section{Bocaccio S. paucispinis}

Bocaccio had lower haplotype diversity than most other species, and there was no evidence for mtDNA differentiation between $\mathrm{MB}$ and $\mathrm{SB}\left(\Phi_{\mathrm{ST}}=-0.019\right)$. With microsatellites, bocaccio from $\mathrm{MB}$ and $\mathrm{SB}$ showed only slight differences between populations. While joint analysis of microsatellite loci failed to reveal genetic differentiation using $F$-statistics, a single locus differed between populations $\quad\left(F_{\mathrm{ST}}=0.081 ; \quad R_{\mathrm{ST}}=0.109 ; \quad P<0.05\right)$. Genotype assignment tests, however, were significantly non-random in assigning individuals to their populations of origin $(P=0.011)$. Matala et al. (2004) used microsatellites to show low but significant differentiation of bocaccio along the California coast...

\section{Starry rockfish S. constellatus}

Starry rockfish exhibited high haplotype diversity $(H=0.986)$ with only two haplotypes shared between the populations, as opposed to 17 (in MB) and 20 (SB) private haplotypes. One of the MB haplotypes, which occurs twice in those samples, was highly divergent from all others. There was also no evidence of genetic differentiation between the populations $\left(\Phi_{\mathrm{ST}}=0.000\right)$. Starry rockfish was the only species which failed to reveal any evidence of population substructuring, whether microsatellite loci were considered individually or jointly. The same was true of the assignment tests, where genotype assignments occurred exactly as expected by chance $(P=1.000)$.

\section{Vermilion rockfish S. miniatus}

A number of unusual patterns emerged for vermilion rockfish (Table 5). 
Table 5 Pairwise measures of population differentiation in Sebastes spp

\begin{tabular}{|c|c|c|c|c|c|c|c|}
\hline Blue & & MB vs OR & MB vs SB & OR vs SB & $\mathrm{N}(\mathrm{MB})$ & $\mathrm{N}(\mathrm{OR})$ & $N(S B)$ \\
\hline \multirow[t]{2}{*}{ Sal2 } & $F_{S T}$ & 0.1249 & 0.0341 & 0.0271 & 23 & 18 & 23 \\
\hline & $\mathrm{R}_{\mathrm{ST}}$ & 0.6164 & 0.2162 & 0.246 & 0.913 & 0.5 & 0.565 \\
\hline \multirow[t]{2}{*}{ Sal3 } & & 0.1129 & 0.0475 & 0.0131 & 15 & 20 & 17 \\
\hline & & 0.0006 & 0.0577 & -0.0142 & 0.933 & 0.7 & 0.706 \\
\hline \multirow[t]{2}{*}{ Sma10 } & & 0.1703 & 0.0238 & 0.1791 & 18 & 20 & 20 \\
\hline & & 0.1306 & -0.0265 & 0.14 & 0.667 & 0.75 & 0.619 \\
\hline \multirow[t]{2}{*}{ Sra7-2 } & & 0.2124 & 0.0098 & 0.1301 & 14 & 15 & 17 \\
\hline & & -0.0149 & 0.0212 & 0.1247 & 0.786 & 0.533 & 0.882 \\
\hline \multirow[t]{2}{*}{ Sra7-7 } & & 0.0861 & -0.0058 & 0.0953 & 16 & 14 & 17 \\
\hline & & -0.032 & -0.0174 & -0.0287 & 0.875 & 0.625 & 0.857 \\
\hline \multirow[t]{2}{*}{ All loci } & & 0.084 & 0.003 & -0.0193 & & & \\
\hline & & 0.459 & 0.1828 & 0.0901 & & & \\
\hline \multirow[t]{2}{*}{ Loci in HWE } & & 0.1468 & 0.0216 & 0.1076 & & & \\
\hline & & 0.0098 & 0.0005 & 0.0629 & & & \\
\hline Control region & $F_{S T}$ & 0.2468 & 0.0235 & 0.1862 & 22 & 23 & 28 \\
\hline Black & & MB vs OR & $\mathrm{N}(\mathrm{MB})$ & $\mathrm{N}(\mathrm{OR})$ & & & \\
\hline \multirow[t]{2}{*}{ Sal2 } & & -0.0055 & 23 & 20 & & & \\
\hline & & -0.0239 & 0.348 & 0.15 & & & \\
\hline \multirow[t]{2}{*}{$\mathrm{Sal3}$} & & 0.0088 & 21 & 17 & & & \\
\hline & & -0.0272 & 0.952 & 0.706 & & & \\
\hline \multirow[t]{2}{*}{ Sma2 } & & 0.0023 & 20 & 22 & & & \\
\hline & & -0.0163 & 0.75 & 0.909 & & & \\
\hline \multirow[t]{2}{*}{ Sma5 } & & 0.0035 & 23 & 23 & & & \\
\hline & & -0.007 & 0.783 & 0.957 & & & \\
\hline \multirow[t]{2}{*}{ Sra7-2 } & & -0.0126 & 24 & 16 & & & \\
\hline & & -0.0159 & 1 & 1 & & & \\
\hline \multirow[t]{2}{*}{ Sra7-7 } & & 0.0287 & 23 & 20 & & & \\
\hline & & 0.0251 & 0.826 & 0.9 & & & \\
\hline \multirow[t]{2}{*}{ All loci } & & -0.0161 & & & & & \\
\hline & & 0.0109 & & & & & \\
\hline \multicolumn{2}{|l|}{ Control region } & 0.0451 & 24 & 19 & & & \\
\hline \multirow{3}{*}{$\begin{array}{l}\text { Olive } \\
\text { Sal2 }\end{array}$} & & MB vs SB & $N(M B)$ & $\mathrm{N}(\mathrm{SB})$ & & & \\
\hline & & 0.0066 & 20 & 19 & & & \\
\hline & & 0.0063 & 0.65 & 0.842 & & & \\
\hline \multirow[t]{2}{*}{ Sal3 } & & -0.0019 & 23 & 19 & & & \\
\hline & & 0.0188 & 0.87 & 0.895 & & & \\
\hline \multirow[t]{2}{*}{ Sma2 } & & 0.0082 & 23 & 22 & & & \\
\hline & & -0.0037 & 0.957 & 0.864 & & & \\
\hline \multirow[t]{2}{*}{ Sma5 } & & 0.0227 & 23 & 21 & & & \\
\hline & & -0.0143 & 0.696 & 0.429 & & & \\
\hline Sma10 & & -0.0181 & 23 & 22 & & & \\
\hline & & -0.0227 & 0.739 & 0.909 & & & \\
\hline Sra7-2 & & 0.0069 & 19 & 18 & & & \\
\hline & & 0.0074 & 0.947 & 0.778 & & & \\
\hline Sra7-7 & & 0.0542 & 21 & 19 & & & \\
\hline & & -0.0116 & 0.571 & 0.778 & & & \\
\hline All loci & & 0.0101 & & & & & \\
\hline & & 0.0153 & & & & & \\
\hline Loci in HWE & & 0.0196 & & & & & \\
\hline & & 0.0142 & & & & & \\
\hline Control region & & 0.0104 & 30 & 33 & & & \\
\hline
\end{tabular}


Table 5 continued

\begin{tabular}{|c|c|c|c|c|c|c|}
\hline Copper & $M B$ vs $O R$ & $M B$ vs $S B$ & OR vs SB & $\mathrm{N}(\mathrm{MB})$ & $\mathrm{N}(\mathrm{OR})$ & $N(S B)$ \\
\hline \multirow[t]{2}{*}{ Sal2 } & -0.0264 & 0.0353 & 0.0629 & 15 & 16 & 9 \\
\hline & -0.0222 & 0.0419 & -0.0263 & 0.667 & 0.563 & 0.889 \\
\hline \multirow[t]{2}{*}{ Sal3 } & 0.0332 & -0.0288 & 0.0292 & 16 & 16 & 9 \\
\hline & -0.0287 & -0.0399 & -0.0329 & 0.875 & 0.625 & 1 \\
\hline \multirow[t]{2}{*}{ Sma2 } & -0.0111 & -0.0201 & 0.0099 & 17 & 17 & 9 \\
\hline & 0.0152 & -0.0442 & -0.0076 & 0.176 & 0.118 & 0.333 \\
\hline \multirow{2}{*}{ Sma5 } & 0.0147 & -0.0023 & -0.0319 & 17 & 17 & 9 \\
\hline & -0.027 & -0.0023 & -0.0156 & 0.294 & 0.176 & 0.111 \\
\hline \multirow[t]{2}{*}{ Sma10 } & 0.0055 & 0.0107 & 0.0651 & 23 & 21 & 9 \\
\hline & -0.0179 & 0.0874 & 0.1319 & 0.957 & 0.905 & 0.778 \\
\hline \multirow[t]{2}{*}{ All loci } & 0.0068 & -0.0137 & 0.034 & & & \\
\hline & -0.056 & -0.0459 & -0.0236 & & & \\
\hline Control region & 0.0209 & 0.1214 & 0.0719 & 18 & 18 & 9 \\
\hline Gopher & MB vs SB & $N(M B)$ & $\mathrm{N}(\mathrm{SB})$ & & & \\
\hline \multirow[t]{2}{*}{ Sal2 } & -0.001 & 24 & 23 & & & \\
\hline & 0.1238 & 0.667 & 0.696 & & & \\
\hline \multirow[t]{2}{*}{ Sal3 } & 0.041 & 23 & 24 & & & \\
\hline & 0.0134 & 0.783 & 0.75 & & & \\
\hline \multirow[t]{2}{*}{ Sma2 } & 0.0022 & 21 & 20 & & & \\
\hline & -0.0121 & 0.524 & 0.55 & & & \\
\hline \multirow[t]{2}{*}{ Sma5 } & 0.091 & 22 & 21 & & & \\
\hline & 0.0491 & 0.636 & 0.381 & & & \\
\hline \multirow[t]{2}{*}{ Sma10 } & 0.0143 & 12 & 21 & & & \\
\hline & -0.0333 & 0.917 & 0.857 & & & \\
\hline \multirow[t]{2}{*}{ Sra7-7 } & 0.0303 & 16 & 23 & & & \\
\hline & 0.2569 & 0.625 & 0.913 & & & \\
\hline \multirow[t]{2}{*}{ All loci } & 0.006 & & & & & \\
\hline & -0.0612 & & & & & \\
\hline Control region & 0.0642 & 18 & 26 & & & \\
\hline Brown & $M B$ vs $S B$ & $N(M B)$ & $\mathrm{N}(\mathrm{SB})$ & & & \\
\hline \multirow[t]{2}{*}{ Sal2 } & 0.0378 & 24 & 23 & & & \\
\hline & -0.0148 & 0.375 & 0.391 & & & \\
\hline \multirow[t]{2}{*}{ Sal3 } & 0.0237 & 23 & 24 & & & \\
\hline & -0.0136 & 0.696 & 0.917 & & & \\
\hline \multirow[t]{2}{*}{ Sma2 } & -0.0212 & 23 & 19 & & & \\
\hline & -0.0212 & 0.435 & 0.579 & & & \\
\hline \multirow[t]{2}{*}{ Sma5 } & 0.0924 & 23 & 19 & & & \\
\hline & -0.0245 & 0.478 & 0.579 & & & \\
\hline Sra7-2 & 0.005 & 18 & 21 & & & \\
\hline & -0.0255 & 0.5 & 0.667 & & & \\
\hline All loci & 0.0221 & & & & & \\
\hline & -0.0202 & & & & & \\
\hline Control region & 0.0055 & 23 & 29 & & & \\
\hline Yellowtail & MB vs OR & MB vs SB & OR vs SB & $N(M B)$ & $\mathrm{N}(\mathrm{OR})$ & $\mathrm{N}(\mathrm{SB})$ \\
\hline Sal2 & 0.0689 & -0.0086 & 0.0356 & 25 & 29 & 22 \\
\hline & 0.1712 & 0.0584 & 0.0241 & 0.92 & 0.724 & 0.864 \\
\hline Sal3 & -0.0016 & -0.0116 & -0.0109 & 32 & 32 & 21 \\
\hline & -0.007 & -0.0183 & -0.0028 & 0.719 & 0.75 & 0.619 \\
\hline Sra7-2 & 0.0191 & 0.015 & 0.0273 & 26 & 6 & 16 \\
\hline & 0.2256 & -0.0246 & 0.2163 & 0.654 & 0.767 & 0.875 \\
\hline Sra7-7 & -0.0036 & 0.0242 & 0.0734 & 30 & 34 & 23 \\
\hline & 0.042 & 0.0279 & 0.1742 & 0.852 & 0.862 & 1 \\
\hline Sma4 & 0.0373 & -0.0073 & 0.0417 & 26 & 30 & 16 \\
\hline & -0.0166 & 0.0293 & 0.0091 & 0.654 & 0.5 & 0.688 \\
\hline Sma10 & 0.016 & -0.014 & 0.0045 & 27 & 29 & 15 \\
\hline & -0.0172 & -0.0199 & -0.0233 & 0.5 & 0.529 & 0.435 \\
\hline
\end{tabular}


Table 5 continued

\begin{tabular}{|c|c|c|c|c|c|c|}
\hline \multirow[t]{2}{*}{ All loci } & -0.0456 & -0.0083 & -0.03 & & & \\
\hline & 0.0449 & 0.0227 & -0.0006 & & & \\
\hline \multirow[t]{2}{*}{ Loci in HWE } & 0.0275 & -0.0213 & 0.0058 & & & \\
\hline & 0.0944 & 0.0321 & 0.0241 & & & \\
\hline Control region & 0.2542 & -0.0141 & 0.1909 & 27 & 18 & 22 \\
\hline Widow & MB vs SB & $\mathrm{N}(\mathrm{MB})$ & $N(S B)$ & & & \\
\hline \multirow[t]{2}{*}{ Sal2 } & 0.026 & 22 & 21 & & & \\
\hline & 0.026 & mono & 0.09524 & & & \\
\hline \multirow[t]{2}{*}{ Sal3 } & 0.0045 & 20 & 19 & & & \\
\hline & 0.012 & 0.65 & 0.84211 & & & \\
\hline \multirow[t]{2}{*}{ Sma2 } & 0.0102 & 22 & 16 & & & \\
\hline & 0.0102 & mono & 0.0625 & & & \\
\hline \multirow[t]{2}{*}{ Sma5 } & 0.0059 & 22 & 20 & & & \\
\hline & 0.0255 & 0 & 0.05 & & & \\
\hline \multirow[t]{2}{*}{ Sma10 } & 0.0865 & 22 & 19 & & & \\
\hline & -0.0245 & 0.68182 & 0.57895 & & & \\
\hline \multirow[t]{2}{*}{ Sra7-2 } & -0.0134 & 24 & 16 & & & \\
\hline & -0.0205 & 0.45833 & 0.1875 & & & \\
\hline \multirow[t]{2}{*}{ Sra7-7 } & -0.0072 & 22 & 14 & & & \\
\hline & -0.029 & 0.54545 & 0.64286 & & & \\
\hline \multirow[t]{2}{*}{ All loci } & 0.0127 & & & & & \\
\hline & -0.0265 & & & & & \\
\hline Control region & -0.0238 & 15 & 36 & & & \\
\hline Bocaccio & MB vs SB & $\mathrm{N}(\mathrm{MB})$ & $\mathrm{N}(\mathrm{SB})$ & & & \\
\hline \multirow[t]{2}{*}{ Sal2 } & 0.0056 & 20 & 15 & & & \\
\hline & -0.0181 & 0.95 & 0.8 & & & \\
\hline \multirow[t]{2}{*}{ Sal3 } & 0.0087 & 17 & 12 & & & \\
\hline & -0.0209 & 0.588 & 0.583 & & & \\
\hline \multirow[t]{2}{*}{ Sma2 } & -0.0095 & 24 & 16 & & & \\
\hline & -0.0239 & 0.917 & 0.625 & & & \\
\hline \multirow[t]{2}{*}{ Sma5 } & -0.0033 & 24 & 16 & & & \\
\hline & 0.0254 & 0.625 & 0.625 & & & \\
\hline \multirow[t]{2}{*}{ Sma10 } & 0.0805 & 19 & 16 & & & \\
\hline & 0.1085 & 0.684 & 0.875 & & & \\
\hline \multirow[t]{2}{*}{ Sra7-2 } & -0.0183 & 20 & 14 & & & \\
\hline & -0.0172 & 0.9 & 0.929 & & & \\
\hline \multirow[t]{2}{*}{ Sra7-7 } & -0.017 & 20 & 13 & & & \\
\hline & -0.0105 & 0.75 & 1 & & & \\
\hline All loci & -0.0013 & & & & & \\
\hline & -0.0008 & & & & & \\
\hline HWE loci & -0.0036 & & & & & \\
\hline & 0.0089 & & & & & \\
\hline Control region & -0.0189 & 10 & 14 & & & \\
\hline Starry & MB vs SB & $\mathrm{N}(\mathrm{MB})$ & $\mathrm{N}(\mathrm{SB})$ & & & \\
\hline Sal2 & 0.0411 & 22 & 18 & & & \\
\hline & 0.0238 & 0.182 & 0.5 & & & \\
\hline Sal3 & -0.0142 & 24 & 17 & & & \\
\hline & -0.0245 & 0.708 & 0.588 & & & \\
\hline Sma2 & 0.0014 & 23 & 20 & & & \\
\hline & -0.0231 & 0.435 & 0.4 & & & \\
\hline Sma5 & -0.0166 & 24 & 21 & & & \\
\hline & -0.0128 & 0.583 & 0.571 & & & \\
\hline Sra7-2 & 0.0039 & 20 & 17 & & & \\
\hline & -0.0235 & 0.7 & 0.765 & & & \\
\hline All loci & -0.0183 & & & & & \\
\hline & -0.0286 & & & & & \\
\hline Control region & 0.0002 & 27 & 28 & & & \\
\hline
\end{tabular}


Table 5 continued

\begin{tabular}{lrrrr} 
Vermilion & MB vs SB & \multicolumn{2}{c}{$N(\mathrm{MB})$} & $\mathrm{N}(\mathrm{SB})$ \\
Sal2 & 0 & 16 & 27 \\
& 0 & mono & mono \\
Sal3 & 0.1723 & 14 & 24 \\
& 0.237 & 0.571 & 0.708 \\
Sma2 & -0.0122 & 14 & 30 \\
& -0.0242 & 0.643 & 0.567 \\
Sma5 & 0.0137 & 14 & 27 \\
& 0.0275 & 0.429 & 0.741 \\
Sma10 & 0.0098 & 15 & 19 \\
& 0.0893 & 0.733 & 0.737 \\
Sra7-2 & 0.0406 & 13 & 17 \\
& -0.009 & 0.615 & 0.824 \\
Sra7-7 & 0.0087 & 9 & 26 \\
& -0.0386 & 0.556 & 0.769 \\
All loci & 0.0049 & & \\
& 0.0456 & & \\
Loci in HWE & 0.0098 & & \\
& 0.0893 & & \\
Control region & 0.0068 & 16 & 47
\end{tabular}

For each pairwise comparison, measures of $F_{\mathrm{ST}}$ (in italics) and $R_{\mathrm{ST}}$ are given for individual microsatellite loci, as well as joint analysis of all loci. In instances where loci were not in HWE, results are presented with and without those loci included in the analyses. The last line of each section shows pairwise $\Phi_{\mathrm{ST}}$ for control region sequences. Values in bold indicate statistical significance $(P<0.05)$. The columns following the pairwise comparisons list sample sizes for each locus for each population (first row) and observed heterozygosity at that locus for that population (second row). Gray shading indicates non-conformance with HWE for that locus in that population. None of the comparisons based on individual microsatellite loci is significant after Bonferroni correction for multiple comparisons

\section{References}

Addison JA, Ort BS, Mesa KA, Pogson GH (2008) Range-wide genetic homogeneity in the California sea mussel (Mytilus californianus): a comparison of allozymes, nuclear DNA markers, and mitochondrial DNA sequences. Mol Ecol 17:4222-4232

Avise JC (1992) Molecular population structure and the biogeographic history of a regional fauna: a case history with lessons for conservation biology. Oikos 63:62-76

Avise JC (1996) Toward a regional conservation genetics perspective: phylogeography of faunas in the southeastern United States. In: Avise JC, Hamrick JL (eds) Conservation genetics: case histories from nature. Chapman and Hall, New York, pp 431-470

Barber PH, Palumbi SR, Erdmann MV, Moosa MK (2002) Sharp genetic breaks among populations of Haptosquilla pulchella (Stomatopoda) indicate limits to larval transport: patterns, causes, and consequences. Mol Ecol 11:659-674

Berger E (1973) Gene-enzyme variation in three sympatric species of Littorina. Biol Bull 145:83-90

Bernardi G (2000) Barriers to gene flow in Embiotoca jacksoni, a marine fish lacking a pelagic larval stage. Evolution 54:226-237

Bernardi G (2005) Phylogeography and demography of sympatric sister surfperch species, Embiotoca jacksoni and E. lateralis along the California coast: historical versus ecological factors. Evolution 59:386-394

Blanchette CA, Melissa Miner C, Raimondi PT, Lohse D, Heady KEK, Broitman BR (2008) Biogeographical patterns of rocky intertidal communities along the Pacific coast of North America. J Biogeogr 35:1593-1607

Bohonak AJ (1999) Dispersal, gene flow, and population structure. Q Rev Biol 74:21-45

Braby CE, Somero GN (2006) Ecological gradients and relative abundance of native (Mytilus trossulus) and invasive (Mytilus galloprovincialis) blue mussels in the California hybrid zone. Mar Biol 148:1249-1262
Buonaccorsi VP, Kimbrell CA, Lynn EA, Vetter RD (2002) Population structure of copper rockfish (Sebastes caurinus) reflects postglacial colonization and contemporary patterns of larval dispersal. Can J Fish Aquat Sci 59:1374-1384

Buonaccorsi VP, Westerman M, Stannard J, Kimbrell C, Lynn E, Vetter RD (2004) Molecular genetic structure suggests limited larval dispersal in grass rockfish, Sebastes rastrelliger. Mar Biol 145:779-788

Buonaccorsi VP, Kimbrell CA, Lynn EA, Vetter RD (2005) Limited realized dispersal and introgressive hybridization influence genetic structure and conservation strategies for brown rockfish, Sebastes auriculatus. Conserv Genet 6:697-713

Burford MO, Bernardi G (2008) Incipient speciation within a subgenus of rockfish (Sebastosomus) provides evidence of recent radiations within an ancient species flock. Mar Biol 154:701-717

Burton RS (1998) Intraspecific phylogeography across the point conception biogeographic boundary. Evolution 52:734-745

Carr M, Syms C (2006) Recruitment. In: Allen LG, Pondella DJ, Horn MH (eds) The ecology of marine fishes: California and adjacent waters. University of California Press, Berkeley, pp 411-427

Connolly SR, Roughgarden J (1998) A latitudinal gradient in Northeast Pacific intertidal community structure: evidence for an oceanographically based synthesis of marine community theory. Am Nat 151:311-326

Connolly SR, Menge BA, Roughgarden J (2001) A latitudinal gradient in recruitment of intertidal invertebrates in the northeast Pacific Ocean. Ecology 82:1799-1813

Cope JM (2004) Population genetics and phylogeography of the blue rockfish (Sebastes mystinus) from Washington to California. Can J Fish Aquat Sci 61:332-342

Dannewitz J, Maes GE, Johansson L, Wickström H, Volckaert FAM, Järvi T (2005) Panmixia in the European eel: a matter of time.... Proc R Soc B Biol Sci 272:1129-1137

Dawson MN (2001) Phylogeography in coastal marine animals: a solution from California? J Biogeogr 28:723-736 
Doherty PJ, Planes S, Mather P (1995) Gene flow and larval duration in seven species of fish from the Great Barrier Reef. Ecology 76:2373-2391

Duda TF, Palumbi SR (1999) Developmental shifts and species selection in gastropods. Proc Natl Acad Sci USA 96:10272-10277

Edmands S, Moberg PE, Burton RS (1996) Allozyme and mitochondrial DNA evidence of population subdivision in the purple sea urchin Strongylocentrotus purpuratus. Mar Biol 126:443-450

Eigenmann $\mathrm{CH}$, Beeson $\mathrm{CH}$ (1893) Preliminary note on the relationship of the species usually united under the generic name Sebastodes. Am Nat 27:668-671

Flowers JM, Schroeter SC, Burton RS (2002) The recruitment sweepstakes has many winners: genetic evidence from the sea urchin Strongylocentrotus purpuratus. Evolution 56:1445-1453

Foster MS, Schiel DR (1985) The ecology of giant kelp forests in California: a community profile. US Fish Wildl Serv Biol Rep 85:1152

Gilbert-Horvath EA, Larson RJ, Garza JC (2006) Temporal recruitment patterns and gene flow in kelp rockfish (Sebastes atrovirens). Mol Ecol 15:3801-3815

Gunderson DR, Sample TM (1980) Distribution and abundance of rockfish off Washington, Oregon, and California during 1977. Mar Fish Rev 42:2-16

Hansen TA (1982) Modes of larval development in early tertiary neogastropods. Paleobiology 8:367-377

Hellberg ME (1994) Relationships between inferred levels of gene flow and geographic distance in a philopatric coral, Balanophyllia elegans. Evolution 48:1829-1854

Hellberg ME (1996) Dependence of gene flow on geographic distance in two solitary corals with different larval dispersal capabilities. Evolution 50:1167-1175

Hellberg ME, Balch DP, Roy K (2001) Climate-driven range expansion and morphological evolution in a marine gastropod. Science 292:1707-1710

Hyde JR, Vetter RD (2007) The origin, evolution, and diversification of rockfishes of the genus Sebastes (Cuvier). Mol Phylogenet Evol 44:790-811

Hyde JR, Kimbrell CA, Budrick JE, Lynn EA, Vetter RD (2008) Cryptic speciation in the vermilion rockfish (Sebastes miniatus) and the role of bathymetry in the speciation process. Mol Ecol 17:1122-1136

Jablonski D, Lutz RA (1983) Larval ecology of marine benthic invertebrates: paleobiological implications. Biol Rev 58:21-89

Lee WJ, Conroy J, Howell WH, Kocher TD (1995) Structure and evolution of teleost mitochondrial control regions. J Mol Evol 41:54-66

Lenarz WH, Ventresca DA, Graham WM (1995) Explorations of El Niño events and associated biological population dynamics off central California. CalCOFI Rep 36:106-119

Lessios HA, Kessing BD, Pearse JS (2001) Population structure and speciation in tropical seas: global phylogeography of the sea urchin Diadema. Evolution 55:955-975

Love MS, Yoklavich MM, Thorsteinson L (2002) The rockfishes of the Northeast Pacific. University of California Press, Berkeley

Marko PB (2004) 'What's larvae got to do with it?' Disparate patterns of post-glacial population structure in two benthic marine gastropods with identical dispersal potential. Mol Ecol 13:597-611

Matala AP, Gray AK, Gharrett AJ, Love MS (2004) Microsatellite variation indicates population genetic structure of bocaccio. North Am J Fish Manag 24:1189-1202

McManus MA, Cheriton OM, Drake PJ, Holliday DV, Storlazzi CD, Donaghay PL, Greenlaw CF (2005) Effects of physical processes on structure and transport of thin zooplankton layers in the coastal ocean. Mar Ecol Prog Ser 301:199-215

McMillan WO, Raff RA, Palumbi SR (1992) Population genetic consequences of developmental evolution in sea urchins (genus Heliocidaris). Evolution 46:1299-1312
Menge BA, Blanchette C, Raimondi P, Freidenburg T, Gaines S, Lubchenco J, Lohse D, Hudson G, Foley M, Pamplin J (2004) Species interaction strength: testing model predictions along an upwelling gradient. Ecol Monogr 74:663-684

Meyer A, Kocher TD, Basasibwaki P, Wilson AC (1990) Monophyletic origin of Lake Victoria cichlid fishes suggested by mitochondrial DNA sequences. Nature 347:550-553

Miller JA, Shanks AL (2004) Evidence for limited larval dispersal in black rockfish (Sebastes melanops): implications for population structure and marine-reserve design. Can J Fish Aquat Sci 61:1723-1735

Miller KM, Schulze AD, Withler RE (2000) Characterization of microsatellite loci in Sebastes alutus and their conservation in congeneric rockfish species. Mol Ecol 9:240-242

Mulvey M, Newman MC, Vogelbein W, Unger MA (2002) Genetic structure of Fundulus heteroclitus from PAH-contaminated and neighboring sites in the Elizabeth and York Rivers. Aquat Toxicol 61:195-209

Narum SR, Buonaccorsi VP, Kimbrell CA, Vetter RD (2004) Genetic divergence between gopher rockfish (Sebastes carnatus) and back and yellow rockfish (Sebastes chrysomelas). Copeia 2004:926931

Paetkau D, Calvert W, Stirling I, Strobeck C (1995) Microsatellite analysis of population structure in Canadian polar bears. Mol Ecol 4:347-354

Palumbi SR (1996) What can molecular genetics contribute to marine biogeography? An urchin's tale. J Exp Mar Biol Ecol 203:75-92

Palumbi SR (1997) Molecular biogeography of the Pacific. Coral Reefs $16: 47-52$

Palumbi SR (2003) Population genetics, demographic connectivity, and the design of marine reserves. Ecol Appl 13:S146-S158

Palumbi SR, Wilson AC (1990) Mitochondrial DNA diversity in the sea urchins Strongylocentrotus purpuratus and S. droebachiensis. Evolution 44:403-415

Parrish RH, Nelson CS, Bakun A (1981) Transport mechanisms and reproductive success of fishes in the California Current. Biol Oceanogr 1:175-203

Planes S, Lenfant P (2002) Temporal change in the genetic structure between and within cohorts of a marine fish, Diplodus sargus, induced by a large variance in individual reproductive success. Mol Ecol 11:1515-1524

Purcell JFH, Cowen RK, Hughes CR, Williams DA (2006) Weak genetic structure indicates strong dispersal limits: a tale of two coral reef fish. Proc R Soc B Biol Sci 273:1483-1490

Raymond M, Rousset F (1995) GENEPOP (Version 1.2): population genetics software for exact tests and ecumenicism. J Hered 86:248-249

Reeb CA, Arcangeli L, Block BA (2000) Structure and migration corridors in Pacific populations of the Swordfish Xiphius gladius, as inferred through analyses of mitochondrial DNA. Mar Biol 136:1123-1131

Riginos C (2001) Larval spatial distributions and other early lifehistory characteristics predict genetic differentiation in eastern Pacific blennioid fishes. Proc R Soc B Biol Sci 268:1931-1936

Rocha-Olivares A, Kimbrell CA, Eitner BJ, Vetter RD (1999) Evolution of a mitochondrial cytochrome $b$ gene sequence in the species-rich genus Sebastes (Teleostei, Scorpaenidae) and its utility in testing the monophyly of the subgenus Sebastomus. Mol Phylogenet Evol 11:426-440

Roughgarden J, Gaines S, Possingham H (1988) Recruitment dynamics in complex life cycles. Science 241:1460-1466

Rousset F (1997) Genetic differentiation and estimation of gene flow from F-statistics under isolation by distance. Genetics 145:12191228

Sanjuan A, Comesana AS, De Carlos A (1996) Macrogeographic differentiation by mtDNA restriction site analysis in the S. W. 
European Mytilus galloprovincialis Lmk. J Exp Mar Biol Ecol 198:89-100

Schmidt PS, Rand DM (2001) Adaptive maintenance of genetic polymorphism in an intertidal barnacle: habitat-and life-stage-specific survivorship of MPI genotypes. Evolution 55:1336-1344

Schneider S, Roessli D, Excoffier L (2000) Arlequin ver. 2.001: a software for population genetics data analysis. Genetics and Biometry Laboratory, University of Geneva, Switzerland

Shanks AL, Eckert GL (2005) Population persistence of California Current fishes and benthic crustaceans: a marine drift paradox. Ecol Monogr 75:505-524

Shulman MJ, Bermingham E (1995) Early life histories, ocean currents, and the population genetics of Caribbean reef fishes. Evolution 49:897-910

Slatkin M (1995) A measure of population subdivision based on microsatellite allele frequencies. Genetics 139:457-462

Sotka EE, Wares JP, Barth JA, Grosberg RK, Palumbi SR (2004) Strong genetic clines and geographical variation in gene flow in the rocky intertidal barnacle Balanus glandula. Mol Ecol 13:2143-2156
Swofford DL (1998) PAUP*. Phylogenetic analysis using parsimony (* and other methods). Version 4. Sinauer Associates, Sunderland

Waples RS (1987) A multispecies approach to the analysis of gene flow in marine shore fishes. Evolution 41:385-400

Westerman ME, Buonaccorsi VP, Stannard JA, Galver L, Taylor C, Lynn EA, Kimbrell CA, Vetter RD (2005) Cloning and characterization of novel microsatellite DNA markers for the grass rockfish, Sebastes rastrelliger, and cross-species amplification in 10 related Sebastes spp. Mol Ecol Notes 5:74-76

Williams EH, Ralston S (2002) Distribution and co-occurrence of rockfishes (family: Sebastidae) over trawlable shelf and slope habitas of California and southern Oregon. Fish Bull 100:836855

Wimberger P (1999) Isolation and characterization of twelve microsatellite loci for rockfish (Sebastes). Mar Biotechnol 1:311-315

Wishard LN, Utter FM, Gunderson DR (1980) Stock separation of five rockfish species using naturally occurring biochemical genetic markers. Mar Fish Rev 42:64-73 